\title{
Faktor - Faktor yang Mempengaruhi Pengangguran Terbuka di Provinsi Jawa Tengah Tahun 2009-2014
}

(Factors Affecting the Open Unemployment In Central Java Province In 2009-2014)

\author{
Yunani Tiya Kasanah, Anifatul Hanim*, P. Edi Suswandi \\ Program Studi Ekonomi Pembangunan, Fakultas Ekonomi dan Bisni, Universitas Jember (UNEJ) \\ Jln. Kalimantan 37, Jember 68121 \\ E-mail: hanim.feb@unej.ac.id
}

\begin{abstract}
Abstrak
Pengangguran merupakan suatu masalah yang kompleks yang dapat menimbulkan gejala sosial di masyarakat, karena seseorang yang tidak bekerja tidak memperoleh penghasilan. Oleh karena itu perlu dicari solusi untuk mengatasi masalah pengangguran. Penelitian ini bertujuan untuk mengetahui pengaruh upah minimum, angkatan kerja, dan pertumbuhan ekonomi terhadap pengangguran terbuka di Provinsi Jawa Tengah tahun 2009-2014. Data yang digunakan adalah data upah minimum, angkatan kerja, pengangguran terbuka dan pertumbuhan ekonomi. Metode analisis yang digunakan dalam penelitian ini adalah regresi data panel dengan pendekatan fixed effect model (FEM). Berdasarkan hasil analisis, diketahui bahwa variabel upah minimum berpengaruh negatif dan signifikan terhadap variabel pengangguran terbuka di Jawa Tengah, variabel angkatan kerja berpengaruh positif dan signifikan terhadap variabel pengangguran terbuka di Jawa Tengah dan variabel pertumbuhan ekonomi tidak berpengaruh signifikan terhadap variabel pengangguran terbuka di Jawa Tengah.
\end{abstract}

Kata Kunci: Angkatan Kerja Pengangguran Terbuka, Pertumbuhan ekonomi Upah Minimum

\begin{abstract}
Economic development of a country aims to increase social welfare by expanding employment opportunities and direct distribution of income evenly. Uneven economic development would be problematic one of them is unemployment. Unemployment is a complex problem that can lead to social phenomena in society as someone who did not work so it does not earn. It is therefore necessary to find a solution to overcome the problem of unemployment. This study aims to determine the effect of the minimum wage, the labor force and economic growth on unemployment in Central Java province in 2009-2014. The analytical method used in this research is panel data regression with fixed effect model approach (FEM). Based on the analysis, it is known that variable minimum wage a significant negative effect on the variable open unemployment in Central Java, a variable workforce positive and significant effect on the variable open unemployment in Central and variable economic growth does not significantly influence the variables of unemployment in Central Java.
\end{abstract}

Keywords: Unemployment, Minimum Wages, Labor Force, economic growth

\section{Pendahuluan}

Pembangunan ekonomi didefinisikan sebagai suatu proses yang menyebabkan kenaikan pendapatan riil per kapita penduduk suatu negara dalam jangka panjang (Subagiarta, 2012:14). Pembangunan ekonomi bertujuan untuk meningkatkan kesejahteraan masyarakat dengan memperluas kesempatan kerja dan mengarahkan distribusi pendapatan secara merata. Pembangunan ekonomi tidak hanya diukur melalui besarnya Produk Domestik Bruto suatu negara saja tetapi juga diukur dari berbagai aspek lain seperti pendidikan, perkembangan teknologi, peningkatan dalam kesehatan, peningkatan dalam infrastruktur serta peningkatan dalam pemerataan pendapatan. Pembangunan ekonomi yang tidak merata akan menimbulkan berbagai permasalahan pada suatu negara. Permasalahan yang sering dijumpai di negara berkembang yakni masalah kemiskinan dan pengangguran.

Pengangguran adalah seseorang yang tergolong dalam angkatan kerja dan secara aktif mencari pekerjaan tetapi belum memperolehnya (Sukirno,2004:28). Pengangguran merupakan salah satu masalah kompleks yang dihadapi sebagian negara di dunia, baik di negara maju maupun negara berkembang. Dalam hal ini, negara berkembang tidak mampu menghadapi masalah tersebut dengan memberikan tunjangan kepada warga yang menganggur, sedangkan negara maju mampu memberikan tunjangan tersebut. Oleh sebab itu, pengangguran dapat menyebabkan gejala sosial di masyarakat karena seseorang yang tidak bekerja mereka tidak memperoleh penghasilan.

Indonesia merupakan salah satu negara berkembang yang mempunyai tantangan dalam menghadapi masalah pengangguran. Jumlah pengangguran di Indonesia masih tergolong tinggi. Masalah pengangguran terdapat di hampir seluruh provinsi di kepulauan Indonesia, salah satunya adalah Provinsi yang berada di Pulau Jawa yaitu Jawa Tengah. Jumlah pengangguran di Provinsi jawa Tengah menduduki posisi kedua terbesar di Jawa.

Upah Minimum Kabupaten/Kota merupakan salah satu faktor yang mempengaruhi pengangguran terbuka. Menurut Mankiw (2000:154), upah merupakan salah satu faktor yang mempengaruhi tingkat pengangguran sehingga besar kecilnya upah yang di tetapkan oleh pemerintah sangat berpengaruh terhadap tingkat pengangguran yang ada. Setiap kenaikan tingkat upah akan diikuti oeleh turunnya tenaga kerja yang diminta, yang berarti akan menyebabkan meningkatnya pengangguran (Alghofari, 2010). Sebaliknya, apabila tingkat upah turun maka akan diikuti oleh meningkatnya penyerapan tenaga kerja, sehingga dapat dikatakan bahwa jumlah tenaga kerja yang terserap mempunyai hubungan timbal balik dengan tingkat upah. Upah mempunyai pengaruh terhadap jumlah angkatan kerja yang ada. Sehubungan dengan itu, jika

\footnotetext{
* Corresponding Author
} 
upah yang ditetapkan tinggi, maka biaya produksi akan semakin meningkat. Akibatnya, perusahaan melakukan efisiensi dengan cara pengurangan tenaga kerja dan berakibat pada bertambahnya jumlah pengangguran .

Pertumbuhan ekonomi juga merupakan salah satu faktor yang mempengaruh pengangguran terbuka. pertumbuhan ekonomi yang tinggi akan berdampak pada penyerapan tenaga kerja yang artinya jumlah pengangguran akan berkurang. Pertumbuhan ekonomi dapat dihitung berdasarkan perubahan jumlah Produk Domestik Regional Bruto.

Jumlah pertumbuhan yang besar dinilai hanya akan menjadi beban dalam pembangunan karena tidak diimbangi dengan penciptaan kesempatan kerja. Menurut Dumairy (1996:68), jumlah penduduk yang besar memperkecil pendapatan perkapita dan menimbulkan masalah ketenagakerjaan. Pertumbuhan penduduk yang tinggi akan menambah jumlah angkatan kerja. Dewasa ini banyaknya jumlah angkatan kerja tidak diimbangi dengan penciptaan kesempatan kerja baru sehingga permasalahan penduduk akan menambah jumlah pengangguran. banyaknya jumlah penduduk dengan lapangan pekerjaan yang terbatas membuat masalah pengangguran menjadi masalah yang sulit untuk diatasi oleh pemerintah. Berdasarkan latar belakang, maka rumusan masalah yang diajukan dalam penelitian ini adalah seberapa besar pengaruh upah minimum, angkatan kerja dan pertumbuhan ekonomi terhadap jumlah pengangguran terbuka di Provinsi Jawa Tengah periode 2009-2014?.

\section{Metode}

\section{Rancangan atau Desain Penelitian}

Rancangan penelitian antar hubungan antar variabel yang diteliti adalah hubungan korelasional. Horison waktu dalam penelitian merupakan studi time series selama periode waktu tahun 2009-2014. Data yang digunakan adalah data sekunder.

\section{Jenis dan Sumber Data}

Penelitian ini difokuskan untuk mencari pengaruh Upah Minimum, Angkatan Kerja dan Pertumbuhan Ekonomi terhadap pengangguran terbuka di Provinsi Jawa Tengah. Jenis data yang digunakan dalam penelitian ini adalah data sekunder yang bersumber dari data Badan Pusat Statistik. Di samping itu untuk data pendukung lainnya diperoleh dari literatur dan jurnal-jurnal yang berhubungan dengan faktorfaktor yang mempengaruhi pengangguran. Data sekunder tersebut meliputi Upah Minimum, Angkatan Kerja, dan Pertumbuhan ekonomi. Penelitian ini menggunakan data panel di Provinsi Jawa Tengah dalam kurun waktu dari tahun 2009-2014.

\section{Populasi dan Sampel}

Penelitian ini menggunakan populasi data upah minimum, angkatan kerja, dan pertumbuhan ekonomi terhadap pengangguran terbuka di Provinsi Jawa Tengah tahun 20092014.

\section{Metode Analisis}

Metode analisis yang digunakan untuk menganalisis tentang pengaruh Upah Minimum, Pertumbuhan Ekonomi dan Tenaga kerja terhadap pengangguran di Provinsi Jawa Tengah adalah metode data panel dengan menggunakan alat pengolahan data yaitu Eviews. Data ini berbentuk data time series dari tahun 2009-2014 dan cross section yang terdiri dari 29 kabupaten dan 6 kota sehingga data yang digunakan adalah pooled data (data panel). Pendekatan yang sering digunakna untuk membuat model dari data panel adalah Fixed Effect Model dan Random Effect Model. Secara ekonometrika hubungan antara upah minimum, tenaga kerja, dan Pertumbuhan ekonomi terhadap pengangguran terbuka di Jawa Tengah dapat dianalisis dengan menggunakan persamaan (Usman dan Nachrowi, 2006:310) :

$$
\mathrm{Y}_{\mathrm{i}}=\beta \mathrm{o}+\beta 1 \mathrm{X}_{\mathrm{i}}+\mathrm{e}_{\mathrm{i}} ; \mathrm{i}=1,2, \ldots ., \mathrm{N}
$$

Dimana N merupakan banyaknya data cross section

Sementara itu, persamaan time series dapat ditulis dengan:

$$
Y_{t}=\beta o+\beta 1 X_{t}+e_{t} ; t=1,2, \ldots . ., T
$$

Dimana T merupakan banyaknya data time series.

Data panel merupakan data gabungan antara time series dengan cross section maka model persamaannya adalah sebaga berikut:

$$
\mathrm{Y}_{\mathrm{it}}=\beta \mathrm{o}+\beta 1 \mathrm{X}_{\mathrm{it}}+\beta 2 \mathrm{X}_{\mathrm{it}}+\beta 3 \mathrm{X}_{\mathrm{it}}+\mathrm{e}_{\mathrm{it}}
$$

Selanjutkan formulasi tersebut ditransformasikan ke model ekonometrika regresi data panel dalam bentuk log-log dengan persamaan sebagai berikut:

$$
\operatorname{LogJP}_{i t}=\beta o+\beta 1 \log U M_{i t}+\beta 2 \log \mathrm{AK}_{i t}+\beta 3 \log P E_{i t}+e_{i t}
$$

Keterangan :

JP : Jumlah pengangguran

UMK : Upah Minimum

\section{AK : Angkatan Kerja}

PE : Pertumbuhan Ekonomi (PDRB)

ßo : Konstanta

$\beta 1, \beta 2, \beta 3$ : Koefisien regresi masing-masing variabel

e : error

i : $1,2,3, \ldots \ldots, 35$ (data cross section kabupaten/kota di Jawa Tengah)

t : 1,2,3,4, dan 5 (data time series 2009-2014).

\section{Hasil dan Pembahasan}

\section{Hasil}

\section{Hasil Uji Hausman}

Penentuan model yang dilakukan pada uji hausman yaitu

\begin{tabular}{|c|c|c|}
\hline \multicolumn{3}{|c|}{ Correlated Random Effects - Hausman Test } \\
\hline \multicolumn{3}{|l|}{ Pool: Untitled } \\
\hline \multicolumn{3}{|c|}{ Test cross-section random effects } \\
\hline \multirow{2}{*}{ Test Summary } & Chi-Sq. Chi & \\
\hline & Statistic d.f. & Probabilitas \\
\hline Cross-section random & 14.939385 & 30.0019 \\
\hline
\end{tabular}
dengan memilih antara model Fixed Effect Model atau Random Effect Model. Berikut merupakan hasil regresi berdasarkan uji hausman: 
Tabel diatas menunjukkan nilai Chi-Square siatistik sebesar 14.939385 dan nilai Chi-Square df sebesar 3, maka nilai ChiSquare statistik $>$ nilai Chi-Square df. Serta nilai probabilitas sebesar 0.0019 menunjukkan nilai probabilitas $<\alpha(\alpha=5 \%)$. Sehingga model data panel yang dapat digunakan adalah Fixed Effect Model.

\section{Hasil Regresi Data Panel}

Hasil dari uji hausman menunjukkan bahwa model yang tepat adalah Fixed Effect Model (FEM).

\begin{tabular}{|c|c|c|c|c|}
\hline \multirow[b]{2}{*}{ Variable } & \multicolumn{4}{|l|}{ Coeffici } \\
\hline & ent & Std. Error & $\mathrm{t}$-Statistic & Prob. \\
\hline & - & & & \\
\hline & 0.51598 & & & \\
\hline \multirow[t]{3}{*}{$\mathrm{C}$} & 8 & 2.605622 & -0.198029 & 0.8433 \\
\hline & - & & & \\
\hline & 0.44601 & & & \\
\hline \multirow[t]{2}{*}{ LOGUMK? } & 8 & 0.128280 & -3.476914 & 0.0006 \\
\hline & 1.45492 & & & \\
\hline \multirow[t]{3}{*}{ LOGAK? } & 7 & 0.498536 & 2.918399 & 0.0040 \\
\hline & - & & & \\
\hline & 0.04789 & & & \\
\hline LOGPE? & 1 & 0.028061 & -1.706662 & 0.0897 \\
\hline
\end{tabular}

Cross-section

fixed (dummy

variables)

$0.89344 \quad 4.4204$

\begin{tabular}{lcll} 
R-squared & 8 & Mean dependent var & 76 \\
\hline Adjusted & R- 0.87052 & & 0.2610 \\
squared & 7 & S.D. dependent var & 19 \\
\hline
\end{tabular}

\begin{tabular}{lcll} 
S.E. & of 0.09392 & 1.7304 \\
regression & 1 & Akaike info criterion & 37 \\
\hline
\end{tabular}

\begin{tabular}{llll} 
Sum & squared & 1 & 1.1247 \\
resid & .517233 & Schwarz criterion & 70 \\
\hline
\end{tabular}

\subsection{5}

1.4855

\begin{tabular}{llrl} 
Log likelihood & 9 & Hannan-Quinn criter. & 89 \\
\hline 38.9792 & Durbin- & 1.7781
\end{tabular}

\begin{tabular}{llll} 
F-statistic & 8 & Watson stat & 49 \\
\hline & 0.00000
\end{tabular}

Prob(F-statistic) 0

Hasil analisis regresi diperoleh koefisien untuk $\mathrm{X} 1=(-$ $0,446018) \mathrm{X} 2=1,454927$ dan X3 $=(-0,047891)$ dan konstanta sebesar $(-0,515988)$ sehingga diperoleh model persamaan regresi sebagai berikut:

LOGJP $=-0,515988-0,446018^{*}$ LOGUMK $_{\mathrm{it}}+$ $1,454927 *$ LOGAK $_{\text {it }}-0,047891 *$ LOGPE $_{\text {it }}$

Berdasarkan persamaan regresi diatas dapat ditarik kesimpulan sebagai berikut:

1. Nilai konstanta dalam model adalah $-0,515988$, berarti apabila variabel upah minimum, angkatan kerja, dan pertumbuhan ekonomi konstan, maka akan menurunkan besarnya jumlah pengangguran terbuka di Provinsi Jawa Tengah sebesar 0,52 persen yang dipengaruhi oleh variabelvariabel lain diluar penelitian.

2. Nilai elastisitas variabel upah minimum sebesar $-0,446018$ yang berarti apabila terjadi peningkatan upah minimum sebesar 1 persen sementara angkatan kerja dan pertumbuhan ekonomi tetap maka jumlah pengangguran terbuka akan mengalami penurunan sebesar 0,45 persen.

3. Nilai elastisitas variabel angkatan kerja sebesar 1,454927 yang berarti apabila terjadi peningkatan angkatan kerja sebesari 1 persen sementara upah minimum dan pertumbuhan ekonomi tetap maka jumlah pengangguran terbuka akan mengalami peningkatan sebesar 1,45 persen.

4. Nilai elastisitas variabel pertumbuhan ekonomi sebesar $-0,047891$ yang berarti apabila terjadi peningkatan pertumbuhan ekonomi sebesar 1 persen sementara upah minimum dan angkatan kerja tetap maka jumlah pengangguran terbuka akan mengalami penuruan sebesar 0,05 persen.

\section{Pembahasan}

Hasil analisis regresi, menunjukkan upah minimum berpengaruh negatif dan signifikan terhadap pengangguran terbuka di Provinsi Jawa Tengah. Artinya, upah yang tinggi akan menyebabkan penurunan jumlah pengangguran terbuka. Peningkatan penawaran tenaga kerja yang terjadi dikarenakan upah yang meningkat, menyebabkan banyak tenaga kerja tidak dapat terserap pada pasar kerja sektor formal. Hal ini dikarenakan sempitnya lapangan usaha sektor formal yang tidak mampu menyerap kelebihan dalam penawaran tenaga kerja sehingga tenaga kerja yang tidak terserap pada sektor formal akan berpindah pada sektor informal yang menyediakan lapangan usaha dan membutuhkan banyak tenaga kerja. Hasil ini tidak sesuai dengan teori John Stuard Mill yang berpendapat bahwa permintaan dan penawaran tenaga kerja yang menentukan tinggi rendahnya tingkat upah. Dimana penawaran kerja ditentukan oleh jumlah penduduk dan permintaan kerja ditentukan oleh dana upah yang tersedia. Elastisitas penawaran tenaga kerja sangat tinggi dalam menanggapi kenaikan upah. Upah pada umumnya melebihi tingkat penghidupan minimum. Upah dapat naik karena peningkatan cadangan modal yang digunakan untuk membayar upah tenaga kerja atau karena pengurangan jumlah tenaga kerja. Jika upah naik maka penawaran tenaga kerja akan naik. Sehingga persaingan antara pekerja tidak hanya akan menurunkan upah tetapi juga sebagian buruh kehilangan pekerjaan (Jhingan, 1990:132). Hasil penelitian ini mendukung hasil penelitian yang dilakukan oleh Sirait dan Marhaeni (2013) yang menyatakan bahwa upah minimum regional berpengaruh negatif terhadap jumlah pengangguran, 
artinya dengan meningkatnya upah maka dorongan untuk mencari pekerjaan/bekerja oleh penduduk semakin banyak sehingga dapat mengurangi jumlah pengangguran.

Hasil analisis yang dilakukan mengenai hubungan antara variabel angkatan kerja dengan jumlah pengangguran terbuka, menunjukkan bahwa variabel angkatan kerja berpengaruh positif dan signifikan terhadap pengangguran terbuka di Jawa Tengah. Artinya, penambahan jumlah angkatan kerja akan menyebabkan peningkatan pengangguran terbuka di Provinsi Jawa Tengah. Hal ini diduga penambahan angkatan kerja disebabkan karena adanya penambahan usia kerja baru dan pergeseran dari bukan angkatan kerja ke angkatan kerja yang menyebabkan kesempatan kerja meningkat tanpa disertai dengan penciptaan lapangan kerja baru. Hal ini sesuai dengan teori yang dikemukakan oleh Adam Smith yang menjelaskan apabila kekurangan penduduk, produksi marginal adalah lebih tinggi daripada pendapatan per kapita yang berakibat pertambahan penduduk akan menaikkan pendapatan perkapita. Akan tetapi apabila penduduk sudah terlalu banyak, hukum hasil tambahan yang semakin berkurang akan mempengaruhi fungsi produksi, maka produksi marjinal mulai mengalami penurunan. Berdasarkan hal tersebut pendapatan nasional dan pendapatan perkapita menjadi semakin lambat pertumbuhannya (Deliarnov, 2012:30). Perlambatan pertumbuhan pendapatan nasional dan pendapatan perkapita akan menurunkan kegiatan ekonomi sehingga dapat menyebabkan jumlah pengangguran bertambah. Hal ini sesuai dengan penelitian yang dilakukan Prasaja (2013) yaitu jumlah penduduk berpengaruh positif dan signifikan terhadap pengangguran. Artinya terjadinya kenaikan jumlah penduduk akan mengakibatkan bertambahnya jumlah angkatan kerja, sehingga dengan sempitnya lahan pekerjaan yang tersedia tidak mampu menyerap angkatan kerja sepenuhnya atau tidak terserap dalam jumlah banyak yang pada akhirnya pengangguran mengalami peningkatan.

Hasil analisis regresi selanjutnya yang dilakukan terhadap hubungan variabel pertumbuhan ekonomi dengan jumlah pengangguran terbuka, menunjukkan bahwa variabel pertumbuhan ekonomi berpengaruh negatif dan tidak signifikan terhadap jumlah pengangguran terbuka di Jawa Tengah. Tidak signifikan berarti jika ada peningkatan pertumbuhan ekonomi maka tidak akan terlalu berpengaruh dalam penurunan jumlah pengangguran terbuka. Hal ini dikarenakan investasi yang dilakukan pemerintah lebih diarahkan pada padat modal dan kurangnya dukungan pemerintah dalam pengembangan sektor dan kegiatan ekonomi yang menyerap tenaga kerja. Hasil ini sesuai dengan penelitian Fatimah (2015), dimana pertumbuhan ekonomi berpengaruh negatif tetapi tidak signifikan terhadap tingkat pengangguran. Seharusnya setiap perubahan pada tingkat pengangguran terkait dengan pertumbuhan ekonomi, karena pertumbuhan ekonomi terjadi karena adanya peningkatan kapasitas produksi yang akan berhubungan dengan penggunaan tenaga kerja.

\section{Simpulan}

Upah minimum berpengaruh signifikan dan negatif terhadap pengangguran terbuka di Provinsi Jawa Tengah tahun 20092014. Angkatan kerja berpengaruh signifikan dan arah positif terhadap pengangguran terbuka di Provinsi Jawa Tengah tahun 2009-2014. Pertumbuhan ekonomi tidak berpengaruh signifikan terhadap pengangguran terbuka di Provinsi Jawa Tengah tahun 2009-2014.

\section{Ucapan Terima Kasih}

Penulis mengucapkan terima kasih kepada BPS Provinsi Jawa Tengah yang telah memberikan data-data yang diperlukan dalam penelitian, sehingga penelitian ini dapat terselesaikan dengan baik.

\section{Referensi}

Ajija, Scuchrul R., Sari, Dyah W., Dkk. 2011. Cara Cerdas Menguasai Eviews. Jakarta: Salemba Empat.

Alghofari, Farid. 2010. Analisis Tingkat Pengangguran di Indonesia Tahun 1998-2007. Fakultas Ekonomi. Universitas Diponegoro. Semarang.

Arfida. 2003. Ekonomi Sumber Daya Manusia. Jakarta: Ghalia Indah.

Badan Pusat Statistik (BPS). 2007. Nasional. BPS: Nasional.

Badan Pusat Statistik (BPS). 2010. Jawa Tengah Dalam Angka. Jawa Tengah: Badan Pusat Statistik Provinsi Jawa Tengah.

Badan Pusat Statistik (BPS). 2011. Jawa Tengah Dalam Angka. Jawa Tengah: Badan Pusat Statistik Provinsi Jawa Tengah.

Badan Pusat Statistik (BPS). 2012. Jawa Tengah Dalam Angka. Jawa Tengah: Badan Pusat Statistik Provinsi Jawa Tengah.

Badan Pusat Statistik (BPS). 2013. Jawa Tengah Dalam Angka. Jawa Tengah: Badan Pusat Statistik Provinsi Jawa Tengah.

Badan Pusat Statistik (BPS). 2014. Jawa Tengah Dalam Angka. Jawa Tengah: Badan Pusat Statistik Provinsi Jawa Tengah.

Badan Pusat Statistik (BPS). 2015. Jawa Tengah Dalam Angka. Jawa Tengah: Badan Pusat Statistik Provinsi Jawa Tengah.

Badan Pusat Statistik (BPS). 2016. Jawa Tengah. BPS: Provinsi Jawa Tengah.

Boediono. 1993. Ekonomi Makro. Seri Sinopsis Pengantar Ilmu Ekonomi No.2. BPFE: Yogyakarta.

Deliarnov. 2012. Perkembangan Pemikiran Ekonomi (Edisi Ketiga). Jakarta: Rajawali Pers.

Dharmayanti, Yeni. 2011. Analisis Pengaruh PDRB Upah dan Inflasi Terhadap Pengangguran Terbuka di Provinsi Jawa Tengah Tahun 1991-2009. Fakultas Ekonomi. Universitas Diponegoro. Semarang

Dumairy. 1996. Perekonomian Indonesia. Jakarta: Erlangga.

Fatimah. 2015. Analisis Faktor-faktor yang Mempengaruhi Tingkat Pengangguran di Aceh. Malaysia. Fakultas Pasca Sarjana Unversitas Syiah Kuala.

Gujarati, 2011. Dasar-dasar Ekonometrika. Jakarta: Salemba Empat.

Harlik Dkk, Oktober 2013. Faktor-faktor yang Mempengaruhi Kemiskinan dan Pengangguran di Kota Jambi. Jurnal Perspektif Pembiayaan dan Pembangunan Daerah. Vol. 1, No. 2.

Irawan dan Suparmoko. 1979. Ekonomi Pembangunan. Yogyakarta: BPFE.

Jhingan, M.L.. 1990. Ekonomi Pembangunan dan Perencanaan. Jakarta: Rajawali.

Kurniawan, C.D. 2013. Analisis Pengaruh PDRB, UMK, dan Inflasi Terhadapa Tingkat Pengangguran Terbuka di Kota Malang Tahun 1980-2011. Malang. Fakultas Ekonomi dan Bisnis Universitas Brawijaya.

Lestari, A.Z. 2010. Analisis Faktor-faktor yang Mempengaruhi Pertumbuhan Ekonomi Regional di Provinsi Jawa Barat (Periodel 1995-2008). Fakultas Ekonomo. Universitas Islam Negeri Syarif Hidayatullah. Jakarta.

Mankiw, N. Greorgy. 2006. Makroekonomi. Jakarta: Erlangga

Murniasih, Ni Kadek Dkk, 2014. Pengaruh PDRB, Tingkap Upah danTingkat Inflasi Terhadap Pengangguran Terbuka Provinsi Bali Tahun 2003-2013. Vol.4, No. 1. 
Ndraha, Taliziduhu. 2002. Pengantar Teori Pengembangan Sumber Daya Manusia. Jakarta: Rineka Cipta.

Nopirin. 1996. Pengantar Ilmu Ekonomi Makro dan Mikro. Yogyakarta: BPFE.

Prasaja, M.H., 2013. Pengaruh Investasi Asing, Jumlah Penduduk dan Inflasi Terhadapa Pengangguran Terdidik di Jawa Tengah Periode tahun 1980-2011. Fakultas Ekonomi. Universitas Negeri Semarang. Semarang.

Rusmini Dkk, Maret 2012. Pengaruh Inflasi, Pertumbuhan Ekonomi dan Investasi Terhadap Pengangguran di Indonesia (Periode 2001-2010). Jurnal Eko-Regional. Vol.7, No. 1.

Sangadji, Maryam Dkk, Mei 2014. Analisis Pengaruh Inflasi dan Pertumbuhan Ekonomi Terhadap Pengangguran di Kota Ambon. Jurnal Ekonomi. Vol. VIII, No.1.

Simanjuntak, P.J. 1998. Pengantar Ekonomi Sumber Daya Manusia Jakarta: Lembaga Penerbit Fakultas Ekonomi UI.

Sirait, N. \& Marhaeni, A. A. I. N. 2013. Analisis Beberapa Faktor yang Berpengaruh terhadap Jumlah Pengangguran Kabupaten/Kota di Provinsi Bali. E-Jurnal. Bali. Fakultas Ekonomi Universitas Udayana.

Sukirno, Sadono. 2000. Ekonomi Pembangunan Proses, Masalah dan Dasar Kebijakan Pembangunan. Jakarta: UI-Press.

Sukirno, Sadono. 2004. Makroekonomi Teori Pengantar Edisi Ketiga. Jakarta: PT Raja Grafindo Persada.
Sukirno, Sadono. 2006. Makroekonomi Teori Pengantar Edisi Ketiga. Jakarta: PT Raja Grafindo Persada.

Sumarsono, Sonny. 2001. Ekonomi Sumber Daya Manusia dan Ketenagakerjaan. Jember: Univeristas Jember.

Todaro, P.M. 2000. Pembangunan Ekonomi di Dunia Ketiga. Jakarta: Erlangga.

Usman, H. \& Nachrowi, N.D. 2006. Pendekatan Populer dan Praktis Ekonometrika Untuk Analisis Ekonomi dan Keuangan. Jakarta: LPFE UI.

Widarjono, Agus. 2009. Ekonometrika Pengantar dan Aplikasinya. Yogyakarta: Ekonosia.

Winarmo, Wing W. 2011. Analisis Ekonometrika dan Statistika dengan Eviews edisi 3. Yogyakarta: Unit Penerbit dan Percetakan STIM YKPN.

Yudha, O. R. P. 2013. Pengaruh Pertumbuhan Ekonomi, Upah Minimum, Tingkat Pengangguran Terbuka, dan Inflasi terhadap Kemiskinan di Indonesia Tahun 2009-2011. Semarang. Fakultas Ekonomi Universitas Negeri Semarang.

Yudhiarso, S.T. 2015. Analisis Faktor-faktor yang Mempengaruhi Tingkat Pengangguran di Kabupaten Jombang Tahun 2004-2013. Jember. Fakultas Ekonomi. Universitas Jember.

Yuliatin Dkk, Mei 2011. Pengaruh Karakteristik Kependudukan Terhadap Pengangguran di Sumatera Barat. Jurnal Manajemen dan Kewirausahaan, Vol. 2, No. 2 